\section{On the Colour of a Hydrogen Flame}

ACCepting, for the time being, the experiments of $\mathrm{Mr}$. Barrett as sufficient proof that a pure hydrogen flame does not exhibit a blue colour, my "elaborate theory" must, I suppose, seek refuge under the actinic power of the electric light.

Mr. Murphy refers this actinism to the fact " that the electric light is bluer than solar light." the blue rays of the sun's light having been abstracted by absorption. This is a bare fact, and deals solely with the relative proportions of the different coloured rays which reach us from the two sources-it conveys no clue to the reasnn $z 0 h y$ the blue rays have an entity in the first instance.

I would not have it understood that I consider all the high refrangible rays to be due to secondary waves; but $I$ think it possible that some, at least, of those emitted from sources of a very high temperature may owe their existence to this cause. Considering for the moment the electric light, we have a centre of the most intense commotion sending off waves in all directions-a condition necessary, and at the same time eminently favourable, for the production of secondary waves.

With respect to $\mathrm{Mr}$. Barrett's experiments, I intend to repeat them as soon as I can command the time. The absence of the higher refrang.ble rays in a hydrogen flame does not, however, affect the mechanical possibility of the existence of secondary waves; although it would be reasonable to expect their presence in a pure oxy-hydrogen flame, the amplitude of the disturbed particles being necessarily very great.

Hartley Institution, Southampton, April 15.

\section{Another Aurora}

A MAGNIFICENI aurora, scarcely inferior to that of February 4 , was observed here on the evening of the Ioth inst., between $8^{\mathrm{h}} 3 \mathrm{O}^{\mathrm{m}}$ and $9^{\mathrm{h}} 30^{\mathrm{m}}$.

The display was at its greatest beauty about $9^{\mathrm{h}} \mathrm{o}^{\mathrm{m}}$, when the creamy-white streamers attained an altitude of at least $60^{\circ}$ above the $N$. horizon, and formed a fine contrast with a pale rose-pink background. The streamers appeared to proceed from behind a dense mass of stratus cloud which, although a moderate breeze was blowing from the S.W., remained almost stationary and unaltered during the display. The N. horizon was lighted up with a glow as intense as the early twilight on an evening in June.

With a small direct-vision spectroscope by Browning, I could see the line in the green near $\mathrm{F}$, but no others. It was remarkably bright and sharply defined.

Becllord, April 12

Thos. Gwyn E. Elger

\section{Brilliant Meteor}

YESTERDAY afternoon, whilst standing on the lawn of the Observatory with my back to the sun, which was brightly shining, I saw a splendid meteor fall in the south-east. The sky at the time was of an intense blue and cloudless, with the exception of a few cirri in the north and north-west, and the meteor as seen against it presented the appearance of polished silver. The flight of the meteor was almost vertical at an altitude of about $30^{\circ}$, its extent was about $10^{\circ}$, and the trail which seemed to hang in the air and fade away like the trail of a rocket, was at the instant of explosion probably $3^{\circ}$ in length. There was no report accompanying its disruption, or it would certainly have been heard, the neighbourhood being very still at the time.

Immediately on its disappearance I looked at my watch, it was $4^{\text {h }} 36^{\text {s }}$ P.M. G.M.T.

Had the fall occurred after dark I have no doubt but that the meteor would have exhibited a magnificent spectacle, for its brilliancy far exceeded that of the moon as seen by daylight.

During the aurora on the evening of the Ioth I observed at 9. I6 P.M. a peculiar well-defined patch or short band of bright red light, the position of which, as seen from here, was N.N.E. altitude $40^{\circ}$ to $45^{\circ}$. Perhaps other observers may have noticed it, and their observations will give data which may serve to assist in determining the true height of the auroral discharge.

The magnetic disturbance on the roth commenced abruptly at 2 M. $^{2}$, and was greatest luring the hours of daylight, so it is extremely probable, the sky being but partially clouded, that if the aurora was visible before night, some observers may have ween it. I cannot say I have ever seen it myself in the daytime, although I have repeatedly seen cirrus clouds assuming a form very similar to auroral streamers. However, on looking at the magnets and finding them undisturbed at the time, I have concluded that no aurora was taking place.

Kew Observatory, April 13

G. Mathus Whipile

\section{Tide Gauges}

THE subject of the tides is now one in which much interest is taken by the committee of the British Association, and it would be a great boon to many who are in a position to give attention to it, if some of your readers would sutply a description of a self-registering gauge for recording the heights, which should do its work effectively and not very expensively. Many plans are suggested; the difficulty is to know which is the best.

Vicarage, Fleetwood, April is

JAMES PEARSON

\section{NOTES ON THE RAINFALL OF $187 \mathrm{r}$}

THE following are a few particulars of the rainfall of the past year, deduced from daily observations with G!aisher's (Hall's improved) rain gauge* at Fulwell, $\uparrow$ near Twickenham, Middlesex, the place of observation being in lat. $51^{\circ} 26^{\prime} \mathrm{o}^{\prime \prime} \mathrm{N}$. long. $\mathrm{O}^{\circ} 2 \mathrm{O}^{\prime} 53^{\prime \prime} \mathrm{W}$.

The orifice, or receiving surface of the gauge, which is placed horizontally, is $8^{\circ} 00$ inches in diameter $\left(50^{\circ} 26\right.$ in area), the height of the same above the ground being one foot, and, as determined by spirit levelling from Ordnance B.M., 47 feet above mean sea-level.

The results of the observations have been calculated in the imperial system, and metric equivalents are placed in brackets, the use of which (brackets), for the sake of distinction, has been avoided in all other formulæ; they have, in each instance, been calculated to two or three places of decimals, but are here given, so far as is practicable, in whole numbers; the nearest integer, in each instance, having been taken; they have further been calculated upon the hypothesis that the rainfall was equally distributed.

In the following table :-

$$
\left.\begin{array}{l}
a=\text { depth of rainfall in inches } \\
\beta=\text { depth in centimetres } \\
\gamma=\text { number of gallons } \\
\delta=\text { number of hectolitres }
\end{array}\right\} \begin{gathered}
\text { Total fall } \\
\text { per month. } \\
\text { Equivalents } \\
\text { per acre. }
\end{gathered}
$$

\begin{tabular}{|c|c|c|c|c|c|c|}
\hline & & & $\alpha$ & $\beta$ & $\gamma$ & $\delta$ \\
\hline January . & & & 2.03 & $5 \cdot 156$ & 45,675 & 2,074 \\
\hline February & & . & 1.00 & $2 \cdot 540$ & 22,500 & 1,022 \\
\hline March & & 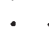 & I.08 & $2 \cdot 743$ & 24,300 & I, I03 \\
\hline April . & $\cdot$ & . & $3 \cdot 5^{2}$ & $8.94 \mathrm{I}$ & 79,200 & 3,596 \\
\hline May. & & . & 0.62 & r.575 & 13,950 & 633 \\
\hline June • • & - & . & $3 \cdot 2 \mathrm{I}$ & $8 \cdot 153$ & 72,225 & 3,279 \\
\hline July : & & . & 3.00 & $7 \cdot 620$ & 67,500 & 3,065 \\
\hline August . & & . & o.93 & $2 \cdot 362$ & 20,925 & $95^{\circ}$ \\
\hline September & 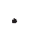 & . & 4.20 & 10.668 & 94,500 & $4,29 \mathrm{~d}$ \\
\hline October. & - & . & I. 10 & $2 \cdot 794$ & 24,750 & $\mathrm{r}, \mathrm{r} 24$ \\
\hline November & - & . & 0.54 & $1 \cdot 372$ & 12,150 & $55^{2}$ \\
\hline December & & & I. 19 & 3.023 & 26,775 & 1,216 \\
\hline
\end{tabular}

The total depth during the year was $22^{\circ} 42$ in., or $56^{\circ} 947$ centimetres.

The rainfall on a square mile during the year was $\overline{22,500 \times 640} \times 22^{\circ} 42=322,848,000$ gallons $\left(\div 22^{\circ} 024=\right.$ I $4,658,9$ I 8 hectolitres), or $640 \times 4840 \times 9 \times 22.42 \div$ I 2 $=52,086,144$ cubic feet $\left(\div 35^{\circ} 31658=1,474,835\right.$ cubic metres).

A cubic inch of distilled water at a temperature of $62^{\circ} \mathrm{F}$ ahr. ( $16.66 \mathrm{C}$.) is a standard of weight ; this quantity has been determined to weigh $252.45^{8}$ grains, of which $437^{\circ} 5$ make one ounce Av. ; therefore, a cubic foot weighs

* Vide Scientific Opinion, Vol. iii., pp. 429; 449 (May x8, 1870 ).

+ Although the observations refer especially to this locality, they will probably be scarcely the les: interesting.

I Practical Meteorology, by John Drew, Ph.D., sec. I27, p. Igo. 